\title{
Physiology of a Methanobacterium Strain AZ
}

\author{
A. J. B. ZEHNDER and K. WUHRMANN \\ Swiss Federal Institute of Technology Zürich and Federal Institute for Water Resources and Water Pollution Control, \\ Überlandstr. 133, CH-8600 Dübendorf, Switzerland
}

Abstract. A methanogenic bacterium using $\mathrm{H}_{2}$ and $\mathrm{CO}_{2}$ as sole energy and carbon source has been isolated in pure culture from digested sludge. Its colonies on mineral agar are translucent, convex, circular with entire margins and yellow to brownish in colour. Cells are gram-positive, non motile and appear as straight rods, normally about $3 \mu \mathrm{m}$ long. A marked pleomorphism depending on the media was observed. The organism is chemolithoheterotrophic, has a $\mathrm{pH}$ optimum of 7.0 and an optimal temperature for growth of $33-40^{\circ} \mathrm{C}$; no growth occurs above $45^{\circ} \mathrm{C}$. The generation time at optimal conditions is less than $5 \mathrm{~h}$. Cysteine must be supplied in the growth medium. It can act as sole sulfur source. The addition of sulfide accelerates the growth at an optimum concentration of $10^{-4}$ to $10^{-5}$ molar. A growth factor, not identical with SH-coenzyme M, occurring in anaerobic sewage sludge and yeast extract shows a stimulatory effect. $7.0-8.2 \%$ of the total carbon dioxide uptake is assimilated and $11.2 \%$ of the energy obtained from the reduction of carbon dioxide to methane is refound in the caloric value of the biomass. $0.01 \mathrm{ppm}$ of dissolved oxygen completely inhibits growth and methane production. However, the bacteria do not loose their viability when exposed to high oxygen concentrations. Further informations are needed before this organism (DSM 744 ) is specifically identified.

Key words: Methanobacterium strain AZ - New isolate - Oxygen effect - Characterization - Physiology.

In the course of our studies on the ecology of methane producers, we isolated an easy to handle methane bacterium for routine research work. We describe the

List of Abbreviations. $\mathrm{TOC}=$ total organic carbon; $\mathrm{DOC}=$ dissolved organic carbon; $\mathrm{POC}=$ particulate organic carbon characteristics of strain $\mathrm{AZ}$ which is a Methanobacterium sp. which utilizes only $\mathrm{H}_{2}$ and has features somewhat similar to Methanobacterium formicicum and Methanobacterium M.O.H.

\section{MATERIALS AND METHODS}

Inocula. Samples of digested sludge from the sewage treatment plant in Opfikon near Zurich were used for enrichment cultures.

Stock Solutions. 1. $\mathrm{KH}_{2} \mathrm{PO}_{4}, 27.2 \mathrm{~g}$ in $1000 \mathrm{ml} \mathrm{H}_{2} \mathrm{O}$. 2. $\mathrm{Na}_{2} \mathrm{HPO}_{4}$, $28.4 \mathrm{~g}$ in $1000 \mathrm{ml} \mathrm{H}{ }_{2} \mathrm{O}$. 3. Mineral solution: $\mathrm{NH}_{4} \mathrm{Cl}, 6 \mathrm{~g}$; $\mathrm{NaCl}$, $6 \mathrm{~g} ; \mathrm{CaCl}_{2} \cdot 2 \mathrm{H}_{2} \mathrm{O}, 2.2 \mathrm{~g} ; \mathrm{MgCl}_{2} \cdot 6 \mathrm{H}_{2} \mathrm{O}, 2 \mathrm{~g}$ in $1000 \mathrm{ml} \mathrm{H}_{2} \mathrm{O}$. 4. $\mathrm{NaHCO}_{3}, 80 \mathrm{~g}$ in $1000 \mathrm{ml} \mathrm{H}_{2} \mathrm{O}$. 5. Trace metal solution: $\mathrm{H}_{3} \mathrm{BO}_{3}$ saturated solution, $1 \mathrm{ml} ; \mathrm{FeCl}_{2} \cdot 2 \mathrm{H}_{2} \mathrm{O}, 2 \mathrm{~g} ; \mathrm{ZnCl}_{2}, 0.05 \mathrm{~g} ; \mathrm{MnCl}_{2}$ . $4 \mathrm{H}_{2} \mathrm{O}, 0.5 \mathrm{~g} ; \mathrm{CuCl}_{2} \cdot 2 \mathrm{H}_{2} \mathrm{O}, 0.03 \mathrm{~g} ;\left(\mathrm{NH}_{4}\right)_{6} \mathrm{Mo}_{7} \mathrm{O}_{24} \cdot 4 \mathrm{H}_{2} \mathrm{O}$, $0.05 \mathrm{~g} ; \mathrm{AlCl}_{3}, 0.05 \mathrm{~g} ; \mathrm{CoCl}_{2} \cdot 6 \mathrm{H}_{2} \mathrm{O}, 2 \mathrm{~g} ; \mathrm{HCl}$ conc. $1 \mathrm{ml}$, in $1000 \mathrm{ml}$ $\mathrm{H}_{2}$ O. 6. Vitamin solution: according to Wolin et al. (1963). 7. Titanium(III) solution $6 \cdot 10^{-2}$ molar (Zehnder, 1976). 8. Sulfide solution: $\mathrm{Na}_{2} \mathrm{~S} \cdot 9 \mathrm{H}_{2} \mathrm{O}, 24.02 \mathrm{~g}$ in $100 \mathrm{ml} \mathrm{H}_{2} \mathrm{O}$.

The sulfate-free enrichment culture medium had the following composition: $20 \mathrm{ml}$ of solution (1) and $47 \mathrm{ml}$ of solution (2) were made up with distilled water to $900 \mathrm{ml}$ and sterilized at $121^{\circ} \mathrm{C}$. $1 \mathrm{ml}$ of trace metal solution (5) and $1 \mathrm{ml}$ of vitamin solution (6) in $50 \mathrm{ml}$ of mineral solution (3) were added aseptically to the autoclaved medium by using a micro-syringe filter holder with a $0.2 \mu \mathrm{m}$ membrane filter (Sartorius $\mathrm{GmbH}$, Göttingen). $0.05 \mathrm{~g}$ of cysteine $\mathrm{HCl}$ in $50 \mathrm{ml}$ of solution (4) were added in the same way. After gassing the medium with $20 \% \mathrm{CO}_{2}$ and $80 \% \mathrm{H}_{2}$ to remove all oxygen, $30 \mathrm{ml}$ of titanium(III) solution and $0.1 \mathrm{ml}$ of sulfide solution were added. Substrates: $\mathrm{H}_{2}$ and $\mathrm{CO}_{2}$.

Growth Medium. Before autoclaving, $2.5 \mathrm{~g}$ yeast extract were dissolved in the mixture of the solutions (1) and (2) as described above. For some experiments, we used the supernatant of digested sewage sludge as a medium. The sludge was centrifuged and the supernatant sterilized by membrane filtration (Sartorius, $0.2 \mu \mathrm{m}$ ). No additions were used besides titanium(III) solution.

Gases. All traces of oxygen in the commercial gases were removed by passing them over heated copper $\left(340^{\circ} \mathrm{C}\right)$ and through columns of Oxisorb (Messer Griesheim, Düsseldorf).

Culture Techniques. The technique described by Hungate (1950, 1969) and modified by Bryant and Robinson (1961) was adapted for isolation and maintenance of the organism. Cultivation of $100 \mathrm{ml}$ cultures: 11 serum bottles with serum caps (diameter $35 \mathrm{~mm}$ ) were used as culture flasks. The enrichment culture media were prepared and sterilized in these bottles as described above. 
Gassing. The culture flasks were evacuated and flushed alternately with the gas mixture and brought to the final pressure as desired. We normally worked at approx. 1.8 atmospheres. The $\mathrm{pH}$ of the medium depends on the carbonate equilibrium and is, therefore, determined by the partial pressure of $\mathrm{CO}_{2}$. The gas phase in the bottles was frequently renewed during the growth of the methane bacteria in order to maintain the substrate concentration and $\mathrm{pH}$ at a constant level. Bottle cultures were shaken at $115 \mathrm{rpm}$ with an amplitude of $5 \mathrm{~cm}$.

A 101 anaerobic fermenter (Bioengineering, Rüti, Switzerland) was used for mass cultures at continuous supply of the substrates $\mathrm{H}_{2}$ and $\mathrm{CO}_{2}$. A constant $\mathrm{pH}$ was achieved by adequate proportioning of the flow of $\mathrm{CO}_{2}$. In this respect it must be remembered that for calculations of $\mathrm{pH}$ in the media from the partial pressure of $\mathrm{CO}_{2}$, the Henry's constant $\left(K_{H}\right)$ has to be included in the equation

$\mathrm{pH}=p K_{1}+p K_{H}+\log \frac{\left[\mathrm{HCO}_{3}^{-}\right]}{p_{\mathrm{CO}_{2}}} \quad$ (Stumm and Morgan, 1970).

For carbon dioxide at $33^{\circ} \mathrm{C}, K_{H}$ is 0.03 . The equilibrium constant $K_{1}$ has to be corrected in solutions with ionic strength of $I>10^{-2} \mathrm{~mol} / \mathrm{l}$. Larson and Buswell (1942) recommend the following salinity correction for the first equilibrium constant: $p K_{1}^{\prime}$ $=p K_{1}-\{0.5 \sqrt{I} /(1+1.4 \sqrt{I})\}$. In our medium $p K_{1}^{\prime}$ is equal to 6.03 .

Analytics. Methane was detected with a Gow Mac gaschromatograph equipped with a Poropak Q $(80 / 100 \mathrm{mesh})$ column and a molecular sieve (100/120 mesh) column connected to a thermal conductivity detector. Samples were taken with sterile Gillette gas tight syringes. Volatile acids and alcohols were identified by a Pye Unicam gas chromatograph equipped with Poropak QS (100/ 120 mesh) columns joined to a flame ionization detector. Programme: $120^{\circ} \mathrm{C}$ for $2 \mathrm{~min}$, then heated to $220^{\circ} \mathrm{C}$ at $4^{\circ} \mathrm{C}$ per min.

Amino acids were chromatographed with an amino acid analyzer (Biocal). Total organic carbon (TOC) and dissolved organic carbon (DOC) were determined with the Beckman analyzer. We calculated particulate organic carbon (POC) from the difference between TOC and DOC.

Bacterial growth was followed by measuring the optical density of bacterial suspensions at $578 \mathrm{~nm}$ with an Eppendorf photometer. Dry weight determinations were performed by using constant weight membrane filters $(0.45 \mu \mathrm{m}$, Sartorius $\mathrm{GmbH}$, Göttingen). Specific rates of methane production,

$Q_{\mathrm{CH}_{4}}$ are given as $\mathrm{ml}_{\left(\mathrm{CH}_{4}\right)} \cdot \mathrm{g}^{-1}$ (dry wt.) $\cdot \min ^{-1}$.

In the present paper, we define the molar growth yield $Y_{\mathrm{CH}_{4}}$ as the mass of cells (dry wt.) per mole of methane released since methane is a very easily detectable product of the energy metabolism of methane bacteria.

Coenzyme $M$ was synthesized according to Taylor and Wolfe (1974). All chemicals were obtained from commercial sources.

\section{RESULTS}

\section{Enrichment, Isolation and Cultivation of the Methanobacterium Strain AZ}

A sample of digested sewage sludge was added to a 11 serum bottle containing $100 \mathrm{ml}$ of enrichment culture medium, an atmosphere of hydrogen and carbon dioxide in such a proportion as to keep the $\mathrm{pH}$ in the medium at 7.0. The flasks were incubated and shaken at $33^{\circ} \mathrm{C}$. Within $72 \mathrm{~h}$, the bottles developed a negative pressure, and methane was present. Transfer of the fermenting medium to roll tubes containing
$80 \% \mathrm{H}_{2}$ and $20 \% \mathrm{CO}_{2}$ produced colonies, some of which were pure cultures of a methane bacterium. Agar surface colonies of this strain which we provisionally called $\mathrm{AZ}$ were translucent, convex, circular with entire margins and yellow to brownish in colour. Cultures of this methane bacterium can be stored in roll tubes at $10^{\circ} \mathrm{C}$ for more than a year without loss of viability. The purity of our strain is easily checked in a growth medium: any formation of organic acids or alcohols or of bad smells from primary amines immediately indicates a contaminant.

\section{Morphological and Physiological Characteristics of Strain $A Z$}

Morphology. Cells of strain AZ, grown at $33^{\circ} \mathrm{C}$ in growth media tend to produce aggregates forming rosettes. The straight rods are $0.5-0.8 \mu \mathrm{m}$ wide and $2-3 \mu \mathrm{m}$ long. They are non motile and gram-positive. Spores are not formed. A significant pleomorphism depending on the medium was observed (Fig. 1).

Optimum Temperature for Growth. Methane bacteria produce methane from $0^{\circ} \mathrm{C}$ in temperate glacier ice (Berner et al., 1975) up to $70^{\circ} \mathrm{C}$ (Methanobacterium thermoautotrophicum, Zeikus and Wolfe, 1972). The optimal temperature for our strain is between $33^{\circ} \mathrm{C}$ and $40^{\circ} \mathrm{C}$; no growth and methane formation occur above $45^{\circ} \mathrm{C}$ (Fig. 2).

Effect of $p H$. In all of our media, $\mathrm{pH}$ is a function of the proportion of $\mathrm{CO}_{2}$ and bicarbonate. The separation of the influence of the two physiological factors $\mathrm{pH}$ and $\mathrm{CO}_{2}$, however, is easily possible by varying either the proportion of $\mathrm{CO}_{2} / \mathrm{HCO}_{3}^{-}$or their absolute concentration at constant proportion. At a $\mathrm{pH}>7.5$, $\mathrm{CO}_{2 a q}$ (or $\mathrm{H}_{2} \mathrm{CO}_{3}$ ) is not present in sufficient quantities for growth in the aqueous medium. This difficulty was avoided by culturing the bacteria under constant gas flow $\left(\mathrm{H}_{2}+\mathrm{CO}_{2}\right)$. All experiments were performed at high and low concentrations of bicarbonate in order to establish its possible influence on growth. The serum bottles used in these experiments were gassed every $90 \mathrm{~min}$ with the adequate gas mixture for ensuring a constant $\mathrm{pH}$. The growth rate of strain $\mathrm{AZ}$ depends directly on the $\mathrm{pH}$, and the optimal $\mathrm{pH}$ is 7.0. Half maximum growth rate is reached at $\mathrm{pH} 6.6$ and 7.4 respectively (Fig. 3).

$\mathrm{CO}_{2}$ the Source of $\mathrm{CH}_{4}$. The relationship between $\mathrm{CO}_{2}$ uptake and $\mathrm{CH}_{4}$ production was determined by measuring $\mathrm{pH}, \mathrm{CO}_{2}, \mathrm{CH}_{4}$ and $\mathrm{POC}$ during growth of strain $\mathrm{AZ}$ in a closed system (serum bottle). Although the measurements of $\mathrm{CO}_{2}$ and $\mathrm{CH}_{4}$ are subject to an experimental error of about $12 \%$ due to the pressure change in the closed system, the results, summarized in Table 1, clearly suggest that $\mathrm{CH}_{4}$ is formed from $\mathrm{CO}_{2}$. 


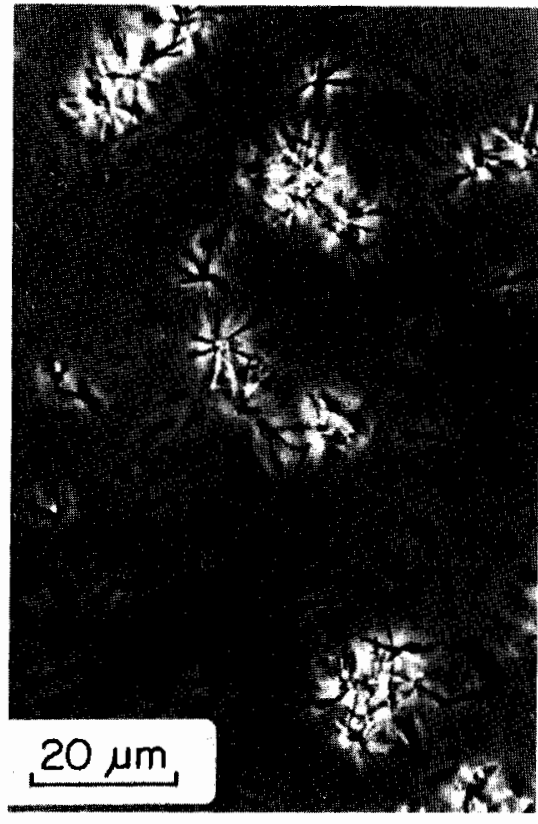

$\mathbf{a}$

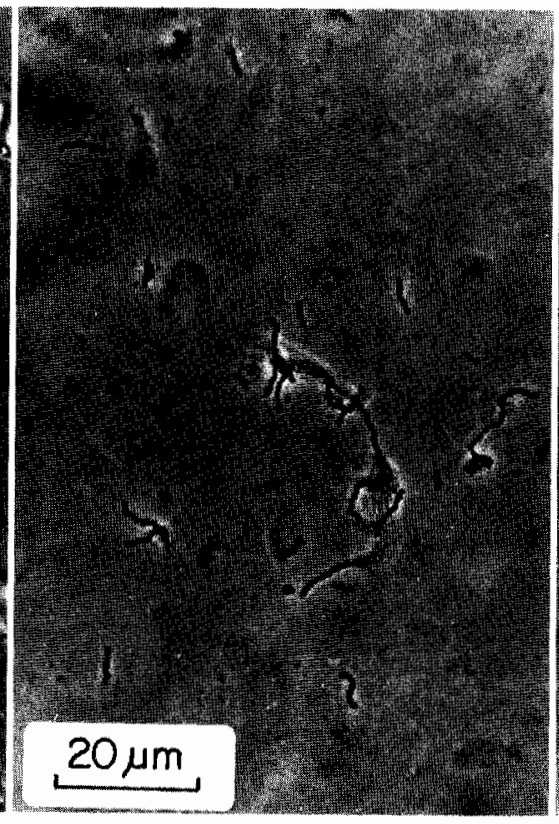

b

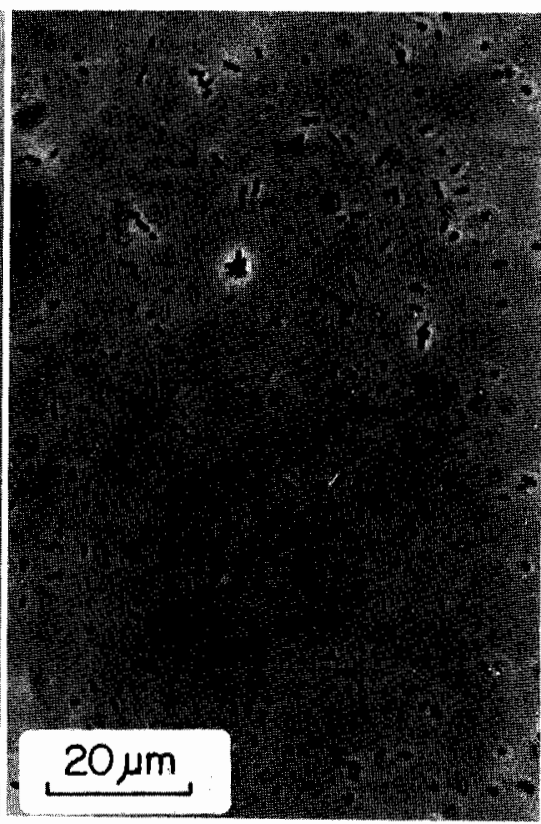

c

Fig. $1 \mathrm{a}-$ c. Pleomorphism of Methanobacterium strain AZ, $33^{\circ} \mathrm{C}$ temperature. (a) Growth medium; growth rate $\mu=0.110 \mathrm{~h}^{-1}$. The cell shape is characteristic for cells grown under optimal conditions. (b) Enrichment medium without vitamins; growth rate $\mu<0.008 \mathrm{~h}^{-1}$. (c) Growth medium without titanium(III) citrate. $0.005 \mathrm{ppm}$ dissolved oxygen were found in the medium. Growth rate $\mu<0.008 \mathrm{~h}^{-1}$. Any of the three forms may be converted into the other ones by transfer to the respective growth conditions
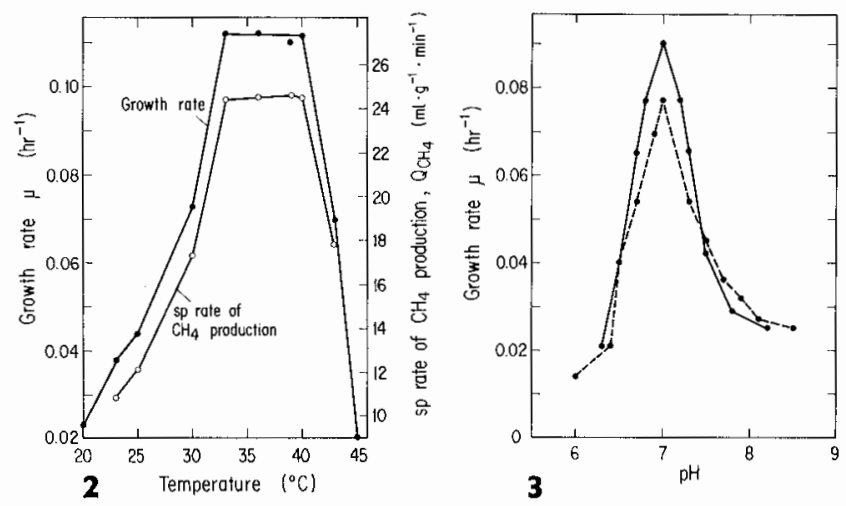

Fig. 2. Optimum temperature for growth and specific methane production of strain AZ. Medium: growth medium. $\mathrm{pH}: 7.0$

Fig. 3. pH dependence of growth of strain AZ. Medium: growth medium. Temperature: $33^{\circ} \mathrm{C}$. - growth in serum bottles (closed system); - growth at constant gas flow $\left(\mathrm{H}_{2}+\mathrm{CO}_{2}\right)$

Hydrogen Tension. Hydrogen tensions up to $2.3 \mathrm{~atm}$. caused no inhibition of growth and methane production. Higher hydrogen pressures were not investigated for safety reasons.

Effect of Oxygen. Methane bacteria are ubiquitous organisms in anaerobic environments where organic matter is decomposed. Methane is produced even when
Table 1. Relationship between $\mathrm{CO}_{2}$ uptake, methane formation and $\mathrm{pH}$ of a growing culture of strain $\mathrm{AZ}$ (growth medium, temperature $=33^{\circ} \mathrm{C}$ )

\begin{tabular}{lllllll}
\hline Time (h) & 0 & 2 & 4 & 6 & 7.5 & 8.5 \\
\hline $\begin{array}{c}\text { Total } \mathrm{CO}_{2} \text { (mmol) } \\
\text { in culture system }\end{array}$ & 1.83 & 1.34 & 0.76 & 0.19 & 0.08 & 0.06 \\
$\mathrm{CH}_{4}$ formed (mmol) & - & 0.44 & 1.05 & 1.59 & 1.79 & 1.86 \\
$\begin{array}{c}\text { Biomass formed } \\
\quad(\text { mmol org. C) }\end{array}$ & - & 0.05 & 0.10 & 0.13 & 0.15 & 0.16 \\
$\mathrm{pH}$ (measured) & 7.53 & 7.67 & 7.91 & 8.37 & 8.70 & 8.82 \\
$\mathrm{pH}^{\mathrm{a}}$ & 7.51 & 7.65 & 7.87 & 8.34 & 8.75 & 8.88 \\
\hline
\end{tabular}

a Calculated according to $\mathrm{CO}_{2} / \mathrm{HCO}_{3}$ equilibrium in the culture system

this environment has originally been aerobic (lake sediments, waste deposits, etc.). The following experiments demonstrated a remarkable oxygen tolerance of our isolate: the atmosphere of $\mathrm{H}_{2}+\mathrm{CO}_{2}$ in the serum bottles of growing cultures was replaced by helium to which oxygen was added in increasing concentrations of $1,2,5,10,20$ and $100 \%$. Since the volume of the gas phase was $1130 \mathrm{ml}$ and the reducing agents in $100 \mathrm{ml}$ of medium were able to remove only $1.64 \mathrm{ml}$ of oxygen, corresponding to $\frac{1.64 \cdot 100}{1130}$ 

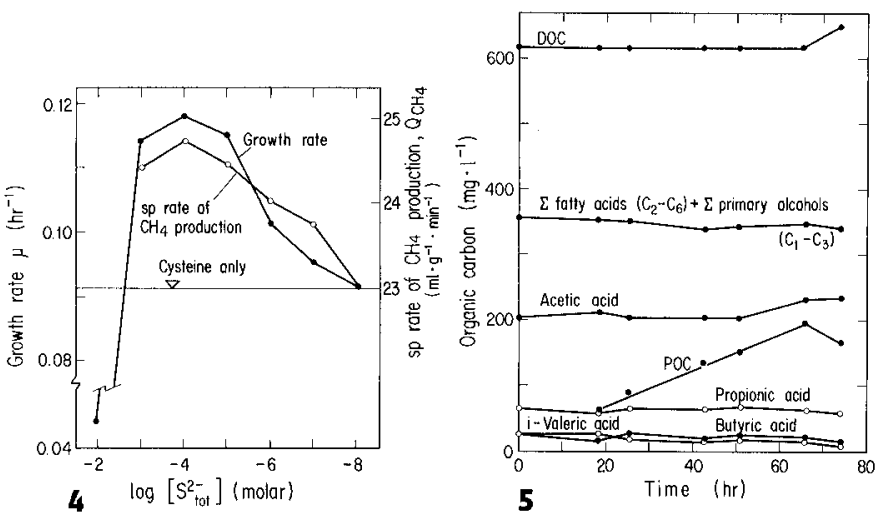

Fig. 4. Effect of various sulfide concentrations on growth and specific methane production of strain $\mathrm{AZ}$. The inoculum was grown in a medium containing cysteine as sole sulfur source. Medium: growth medium. $\mathrm{pH}$ : 7.0 ; temperature: $33^{\circ} \mathrm{C}$

Fig. 5. Concentrations of DOC, POC, volatile acids and alcohols (as organic carbon) in the course of growth of strain AZ. Medium: membrane filtered supernatant of digested sewage sludge. $\mathrm{pH}: 7.0$; temperature: $33^{\circ} \mathrm{C}$. Substrates: $\mathrm{H}_{2}$ and $\mathrm{CO}_{2}$. Variance of acids, alcohols and POC approx. $10 \%$, of DOC approx. $4 \%$. POC in the medium was bacterial biomass. Methanol, ethanol, n-propanol and iso-butyric acid are not stated due to their low concentrations

$=0.145 \%$ of the gas phase, the bacterial environment was strictly aerobic at even the lowest oxygen addition. The culture bottles were then shaken for 4 days at $33^{\circ} \mathrm{C}$. Thereafter, the gas phase was replaced by the original atmosphere, and reducing conditions were restored by injection of titanium(III) solution. Growth and methane production started again within a lag phase of a few hours in the case of oxygen concentrations of $1-5 \%$. It increased to $48 \mathrm{~h}$ after exposition to an atmosphere with $10-20 \%$ oxygen, and the contact of the cultures with pure oxygen delayed regrowth for more than a month. The length of the lag phase was clearly a function of the preceeding oxygen activity in the medium. When oxygen was injected into the culture flasks still containing the $\mathrm{H}_{2} /$ $\mathrm{CO}_{2}$ gas phase, stop of growth and methane production recurred as in the previous experimental arrangements, and the resulting lag phases after removal of the oxygen were similar. The composition of the medium showed no effect on the oxygen tolerance or on the period of recovery.

Role of Sulfide and Cysteine. Sulfide and cysteine are reducing agents; at the same time, however, they might be essential physiological factors for growth. Separation of the two activities is only possible with a reductant which is physiologically inert. Titanium(III) citrate meets excellently the requirements for such a redox buffer at $E_{H}^{o}=-480 \mathrm{mV}, \mathrm{pH} 7.0$ (Zehnder, 1976).
Variation of the sulfide concentration in a medium containing $0.05 \mathrm{~g}$ cysteine $\mathrm{HCl}$ revealed that sulfide accelerates the growth and the methane production at an optimum concentration of $10^{-4}$ to $10^{-5}$ molar (Fig.4). Methionine, thioglycolic acid, ferredoxin (Sigma) or sulfide as sole sulfur source cannot replace cysteine. It must be considered an irreplaceable, essential amino acid to be supplied in the external medium. In the mineral (enrichment) medium, $40 \mu \mathrm{g}$ cysteine per mg biomass produced were consumed. Only $3.6 \mu \mathrm{g}$ cysteine, however, were used during growth in the supernatant of digested sludge. In a later paper (Wellinger et al., in preparation), we shall discuss the role of the sulfur compounds for our strain in more detail.

Utilization of Organic Compounds. Supernatant of digested sludge, sterilized by membrane filtration, was continuously gassed with $\mathrm{H}_{2}$ and $\mathrm{CO}_{2}$ at $\mathrm{pH} 7,33^{\circ} \mathrm{C}$ and was inoculated with strain $\mathrm{AZ}$. The composition of the medium was analyzed during growth. Particular parameters were TOC, DOC, short chained volatile acids and alcohols. The results are presented in Figure 5 which indicates no consumption of any organic compound (constant value of DOC during the growth period). In cultures in the growth medium (containing yeast extract as organic component), no decrease of DOC was observed either.

The following compounds (concentration $1-5 \mathrm{~g} / 1$ ) were assayed for finding other substances which could replace hydrogen for energy supply or carbon dioxide as carbon source and/or as terminal electron acceptor:

1. Fatty acids up to caproate; 2 . alcohols up to tertiary butanol; 3. formaldehyde and acetaldehyde; 4. succinic acid and pyruvate.

These compounds were examined in growth medium with and without hydrogen and carbon dioxide, replacing the absent gas by helium. In all experiments, methane production was exclusively observed in the presence of hydrogen and carbon dioxide. $50 \mathrm{ppm}$ of formaldehyde and acetaldehyde were already poisonous.

Amino Acid Production. In search of possible amino acid requirements (others than cysteine) of strain $\mathrm{AZ}$, the concentrations of amino acids during growth in sludge supernatant were determined. Table 2 shows that none of the analyzed compounds were consumed. On the contrary, a remarkable excretion of most of them occurred into the external medium. We obtained the same results in the mineral enrichment medium. No distinct increase of amino acids could be detected, however, in the growth medium containing yeast extract due to the already high amino acid content of this substrate. 
Table 2. Amino acid production of Methanobacterium strain AZ. Medium : supernatant of digested sewage sludge, sterilized by membrane filtration. Substrates: $\mathrm{H}_{2}+\mathrm{CO}_{2}, \mu=0.058 \mathrm{~h}^{-1} ; \mathrm{Y}_{\mathrm{CH}_{4}}=2.53 \mathrm{~g}$ . $\mathrm{mol}^{-1} ; \mathrm{pH}=7.0$; temperature: $33^{\circ} \mathrm{C}$

\begin{tabular}{|c|c|c|c|}
\hline \multirow[t]{3}{*}{ Amino acid } & \multicolumn{2}{|c|}{ Sludge supernatant } & \multirow{3}{*}{$\begin{array}{l}\text { sp amino } \\
\text { acid pro- } \\
\text { duction } \\
\mu \mathrm{mol} / \mathrm{g} \\
\text { dry wt. } \\
\text { increase }\end{array}$} \\
\hline & $\begin{array}{l}\text { before } \\
\text { growth }\end{array}$ & $\begin{array}{l}\text { after } \\
\text { growth } \\
\text { of } 50 \mathrm{~h}\end{array}$ & \\
\hline & \multicolumn{2}{|l|}{$\mu \mathrm{mol} / 1$} & \\
\hline Aspartic acid & 2.4 & 6.1 & 9.8 \\
\hline Threonine & 6.0 & 14.0 & 21.2 \\
\hline Serine & 3.3 & 16.6 & 35.4 \\
\hline Glutamic acid & 11.7 & 30.0 & 48.6 \\
\hline Glycine & 11.0 & 11.0 & 0 \\
\hline Alanine & 43.4 & 104.6 & 163.2 \\
\hline Valine & 26.0 & 56.2 & 80.6 \\
\hline Methionine & 4.3 & 8.1 & 10.0 \\
\hline Isoleucine & 6.6 & 12.4 & 15.4 \\
\hline Leucine & 8.0 & 20.5 & 33.2 \\
\hline Tyrosine & 2.4 & 4.1 & 4.4 \\
\hline Phenylalanine & 2.7 & 6.4 & 9.8 \\
\hline$\beta$-Alanine & 36.0 & 36.1 & 0 \\
\hline$\beta$-Aminoisobutyric acid & 11.0 & 11.0 & 0 \\
\hline Lysine & 0.7 & 0.7 & 0 \\
\hline Arginine & 0.8 & 1.0 & in traces \\
\hline
\end{tabular}

\section{Growth Rate, Specific Methane Production Rate} and Molar Growth Yield

Growth rate and specific methane production rate were measured in $1000 \mathrm{ml}$ shaken cultures. The molar growth yields, based on methane production (see chapter "Materials and Methods") are contained in Table 3. No significant deviations occurred which could be assigned to the composition of the media. A maximum cell yield of $1.2 \mathrm{~g} / 1$ (dry wt.) was found in a 101 fermenter stirred at $1000 \mathrm{rpm}$, growth medium, $\mathrm{pH} 7,33^{\circ} \mathrm{C}$, hydrogen and $\mathrm{CO}_{2}$ as substrates.

\section{Energy Balance}

The free enthalpy of the lyophylized biomass of our strain was obtained by calorimetric determination. A heat production of $3.57 \mathrm{kcal}$ per $\mathrm{g}$ of biomass was found which permits to establish an overall balance equation for enthalpy changes in the oxidation process as follows:

$$
\begin{array}{rll}
\left(\mathrm{CH}_{2} \mathrm{O}\right)_{(\mathrm{s})}+\mathrm{O}_{2(\mathrm{~g})} & \rightarrow \mathrm{CO}_{2(\mathrm{~g})} & +\mathrm{H}_{2} \mathrm{O} \\
& -94.26 \mathrm{kcal}^{\mathrm{a}} & -56.69 \mathrm{kcal}^{\mathrm{a}} \\
-41.75 \mathrm{kcal}^{\mathrm{c}} & -109.2 \mathrm{kcal}^{\mathrm{b}}
\end{array}
$$

a Values from Latimer (1956)

b Change of free enthalpy, calculated from the heat produced by burning $30 \mathrm{~g}$ of biomass $(30 \cdot 3.57 \mathrm{kcal})$ in the calorimeter

c "Molar"-free enthalpy of biomass, calculated from ${ }^{a}$ and ${ }^{b}$
Table 3. Growth rate $(\mu)$, specific methane production rate $\left(Q_{\mathrm{CH}_{4}}\right)$ and molar growth yield $\left(Y_{\mathrm{CH}_{4}}\right)$ of strain $\mathrm{AZ}$ in various media. Substrates: $\mathrm{H}_{2}+\mathrm{CO}_{2}, \mathrm{pH}: 7.0$, temperature: $33^{\circ} \mathrm{C}$

\begin{tabular}{lccc}
\hline Medium & $\begin{array}{l}\mu \\
\left(\mathrm{h}^{-1}\right)\end{array}$ & $\begin{array}{l}Q_{\mathrm{CH}_{4}} \\
\left(\mathrm{ml} \cdot \mathrm{g}^{-1}\right. \\
\left.\mathrm{min}^{-1}\right)\end{array}$ & $\begin{array}{l}\mathrm{Y}_{\mathrm{CH}_{4}} \\
\left(\mathrm{~g} \cdot \mathrm{mol}^{-1}\right)\end{array}$ \\
\hline $\begin{array}{l}\text { Enrichment medium } \\
\begin{array}{l}\text { Supernatant of digested } \\
\text { sewage sludge }\end{array}\end{array}$ & 0.012 & $2.9 \pm 0.2^{\mathrm{a}}$ & $2.29 \pm 0.21$ \\
$\begin{array}{l}\text { Growth medium } \\
\text { rown }\end{array}$ & 0.058 & $12.3 \pm 0.7$ & $2.53 \pm 0.15$ \\
\hline
\end{tabular}

a Standard deviation of mean of 5-15 assays

According to the experimental findings summarized in Table 3, $2.68 \mathrm{~g}$ of biomass with a free enthalpy of $3.73 \mathrm{kcal}$ is bound to the production of 1 mole methane. Assuming its formation from $\mathrm{CO}_{2}$ and $\mathrm{H}_{2}$ $(-33.23 \mathrm{kcal})$, the energy yield based on biomass of strain $\mathrm{AZ}$ is then $3.73 \mathrm{kcal} / 33.23 \mathrm{kcal}=0.112$ or $11.2 \%$.

\section{DISCUSSION}

The experiments presented show very clearly that the methane bacterium strain $\mathrm{AZ}$ is chemolithotrophic. The energy for growth is exclusively obtained by oxidation of hydrogen, and no other energy substrate such as formate, methanol or acetate can be used. The only terminal electron acceptor is carbon dioxide. Strain AZ is most similar to Methanobacterium formicicum, Methanobacterium strain M.O.H. and Methanobacterium arbophilicum (Zeikus and Henning, 1975), it differs however from these in some features (Table 4):

Further comparative studies such as DNA composition and homologies, ultrastructure and chemical composition of cellular components remain to be investigated before a definitive identification and the taxonomic differentiation from the above strains can be made.

Using titanium(III) citrate as a redox buffer, the metabolic role of sulfide and cysteine could be observed independently from their activities as reductants in the medium. Cysteine seems to be the main sulfur source for strain AZ, and furthermore it is an essential amino acid for growth. In inorganic media, cysteine additionally acts as a complexing agent for trace metals preventing their precipitation when sulfide is added. Sulfide demonstrates an accelerating effect on growth and methane production in the presence of cysteine. It is not yet established whether it serves as an additional sulfur source. The dependence on an external supply of cysteine classifies our organism as partially heterotrophic. Consequently, strain $\mathrm{AZ}$ should be designated as a chemolithoheterotrophic 
Table 4. Comparison of Methanobacterium strain characteristics

\begin{tabular}{|c|c|c|c|c|}
\hline Strain/Characteristic & M. formicicum & M. strain M.O.H. & M. arbophilicum & $M$. strain $\mathrm{AZ}$ \\
\hline Agar colony & rough & rough & rough & smooth \\
\hline Morphology & $\begin{array}{l}\text { rods, single in pairs } \\
\text { or chains }\end{array}$ & $\begin{array}{l}\text { rods, single in pairs } \\
\text { or chains }\end{array}$ & $\begin{array}{l}\text { rods, single in pairs } \\
\text { or chains }\end{array}$ & $\begin{array}{l}\text { rods, single in pairs, } \\
\text { forms rosettes }\end{array}$ \\
\hline $\begin{array}{l}\text { Dimension (length) } \\
\text { pH optimum }\end{array}$ & $2-15 \mu \mathrm{m}$ & $2-4 \mu \mathrm{m}$ & $\begin{array}{l}1.8-3.5 \mu \mathrm{m} \\
7.5-8.0\end{array}$ & $\begin{array}{l}2-3 \mu \mathrm{m} \\
6.8-7.2\end{array}$ \\
\hline $\begin{array}{l}\text { Electron donor } \\
\text { Cysteine }\end{array}$ & $\begin{array}{l}\mathrm{H}_{2}+\text { formate } \\
\text { stimulatory }\end{array}$ & $\begin{array}{l}\mathrm{H}_{2} \\
\text { stimulatory }\end{array}$ & $\begin{array}{l}\mathrm{H}_{2} \\
\text { stimulatory }\end{array}$ & $\begin{array}{l}\mathrm{H}_{2} \\
\text { essential }\end{array}$ \\
\hline
\end{tabular}

bacterium. Partial heterotrophy also exists in regard to some unknown growth stimulating factor(s) occurring in digested sewage sludge or yeast extract.

SH-coenzyme M, even in high concentrations, had no effect on growth and methane formation of strain AZ.

Best growth was observed in a medium containing yeast extract. No stimulation occurred by acetate or other defined organic compounds, as described for M. ruminantium and M. strain M.O.H. (Bryant et al., 1971).

The generation time of strain $\mathrm{AZ}$ of less than $5 \mathrm{~h}$ is much lower than that reported for other methane bacteria with the exception of $M$. thermoautotrophicum (Zeikus and Wolfe, 1972) which shows a similar division rate. The molar growth yields of strain $\mathrm{AZ}$ in complex synthetical medium vary from $Y_{\mathrm{CH}_{4}}=2.29$ to $2.68 \mathrm{~g} \cdot \mathrm{mol}^{-1}$. A value of $Y_{\mathrm{CH}_{4}}=2.32 \mathrm{~g} \cdot \mathrm{mol}^{-1}$ can be calculated for $M$. strain M.O.H. on the basis of the results of Roberton and Wolfe (1970) when hydrogen and carbon dioxide are used as substrates. $Y_{\mathrm{CH}_{4}}=3.3 \mathrm{~g} \cdot \mathrm{mol}^{-1}$ was found by Stadtman (1967) for Methanosarcina barkeri with methanol as sole substrate. It seems that a molar growth yield of about $Y_{\mathrm{CH}_{4}}=2.5 \mathrm{~g} \cdot \mathrm{mol}^{-1}$ is a good approximation for methane producers. Assimilated carbon dioxide accounts for $7.0-8.2 \%$ of the total of carbon dioxide uptake, and $11.2 \%$ of the energy obtained from the overall reaction: $4 \mathrm{H}_{2}+\mathrm{CO}_{2} \rightarrow \mathrm{CH}_{4}+2 \mathrm{H}_{2} \mathrm{O}$ were refound in the caloric value of the biomass.

Methane bacteria are supposed to be extremely sensitive to oxygen. $0.001 \mathrm{ppm}$ of dissolved oxygen partially inhibits growth of $M$. ruminantium, and $0.01 \mathrm{ppm}$ of dissolved oxygen prevents growth completely (these values were calculated on the basis of Hungate's indications, 1966). Paynter and Hungate (1968) found similar results with M. mobile, and so did we with strain AZ. This does not mean, however, that the bacteria are killed by the presence of oxygen. Cultures of strain $\mathrm{AZ}$ exposed to high pressures of oxygen (e.g. $20 \% \mathrm{O}_{2}$ in the gas phase, $7 \mathrm{ppm}$ of dissolved oxygen) for several days regrew and produced methane after removal of all oxygen from the culture flasks and the restoration of reducing conditions in the medium with titanium(III) citrate.

The short generation time, the mesophilic temperature optimum, the high oxygen tolerance and the simple nutritional requirements indicate strain $\mathrm{AZ}$ as an ideal methane bacterium for routine research work.

\section{Summary of Characteristics \\ of Methanobacterium Strain AZ}

Morphology. Straight rods, $0.5-0.8 \mu \mathrm{m}$ in diameter, $2-3 \mu \mathrm{m}$ long. Non motile, gram-positive.

Colony Characteristics. Translucent, convex, circular with entire margins and yellow to brownish in colour.

Sensitivity to Oxygen. Growth at strictly anaerobic and highly reducing conditions. Resistant to oxygen contact.

Temperature optimum $33-40^{\circ} \mathrm{C}$, tolerated maximum $45^{\circ} \mathrm{C}$.

$\mathrm{pH}$ optimum for growth at 7.0, half optimum at $\mathrm{pH} 6.6$ and $\mathrm{pH} 7.4$, respectively.

Nutritional Characteristics. Sole energy source is hydrogen, and sole carbon source is carbon dioxide. No utilization of formate, methanol and acetate. Sole sulfur source is cysteine, sulfide at $10^{-4}$ to $10^{-5}$ molar concentrations stimulates growth remarkably. Best growth is obtained in a medium containing yeast extract.

Coenzyme $\mathrm{M}$ is not required.

Source. Digested sewage sludge.

Type. Strain AZ, isolated from the sewage plant in Opfikon, Zurich, has been deposited in the Deutsche Sammlung von Mikroorganismen (DSM), Göttingen, Germany, under the number DSM 744.

Acknowledgements. We thank Prof. Marvin P. Bryant and Prof. Hans $G$. Schlegel for the critical review of our paper.

\section{REFERENCES}

Berner, W., Bucher, P., Oeschger, H., Stauffer, B.: Analysis and interpretation of gas content and composition in natural ice. 
Symp. on isotopes and impurities in snow and ice: Union géodésique et géophysique internationale, Grenoble, le 25/ $8-6 / 9(1975)$

Bryant, M. P.: Methane-producing bacteria. In: Bergey's manual of determinative bacteriology, 8th ed. (R. E. Buchanan, N. E. Gibbons, eds.), pp. 472-477. Baltimore: Williams and Wilkins 1975

Bryant, M. P., Robinson, I. M.: An improved nonselective culture medium for ruminal bacteria and its use in determining diurnal variation in numbers of bacteria in the rumen. J. Dairy Sci. 44, 1446-1456 (1961)

Bryant, M. P., Tzeng, S. F., Robinson, I. M., Joyner, A. E., Jr.: Nutrient requirements of methanogenic bacteria. In: Anaerobic biological treatment processes. Advances in Chemistry, Series 105 (F. G. Pohland, ed.), pp. 23-40. Washington, D.C.: Am. Chem. Soc. 1971

Bryant, M. P., Wolin, E. A., Wolin, M. J., Wolfe, R. S.: Methanobacillus omelianskii, a symbiotic association of two species of bacteria. Arch. Mikrobiol. 59, 20-31 (1967)

Hungate, R. E.: The anaerobic mesophilic cellulolytic bacteria. Bact. Rev. 14, 1-49 (1950)

Hungate, R. E.: The rumen and its microbes, p. 78. New YorkLondon: Academic Press 1966

Hungate, R. E.: A roll tube method for cultivation of strict anaerobes. In: Methods in microbiology, Vol. 3B (J. R. Norris, D. W. Ribbons, eds.), pp. 117-132. New York-London: Academic Press 1969

Larson, T. E., Buswell, A. M.: Calcium carbonate saturation index and alkalinity interpretations. J. Amer. Water Works Ass. 34, 1667-1684 (1942)
Latimer, W. M.: Oxidation potentials, 2nd ed. Englewood Cliffs, N.J.: Prentice-Hall 1956

Paynter, M. J. B., Hungate, R. E.: Characterization of Methanobacterium mobile, sp.n., isolated from the bovine rumen. J. Bact. 95, $1943-1951$ (1968)

Roberton, A. M., Wolfe, R. S.: Adenosine triphosphate pools in Methanobacterium. J. Bact. 102, 43-51 (1970)

Smith, P. H., Hungate, R. E.: Isolation and characterization of Methanobacterium ruminantium n.sp. J. Bact. 75, 713-718(1958)

Stadtman, T. C.: Methane fermentation. Ann. Rev. Microbiol. 21, $121-142$ (1967)

Stumm, W., Morgan, J. J.: Aquatic chemistry. New York-LondonSydney-Toronto: Wiley 1970

Taylor, C. D., Wolfe, R. S. : Structure and methylation of coenzyme M. J. Biol. Chem. 249, 4879-4885 (1974)

Wolin, E. A., Wolin, M. J., Wolfe, R. S. : Formation of methane by bacterial extracts. J. Biol. Chem. 238, 2882-2886 (1963)

Zehnder, A. J. B.: Oekologie der Methanbakterien, Dissertation, ETHZ, Nr. 5716. Zürich: Juris 1976

Zeikus, J. G., Henning, D. L.: Methanobacterium arbophilicum sp. nov. An obligate anaerobe isolated from wetwood of living trees. Antonie v. Leeuwenhoek 41, 543- 552 (1975)

Zeikus, J. G., Wolfe, R. S.: Methanobacterium thermoautotrophicum sp.n. An anaerobic, autotrophic, extreme thermophile. J. Bact. 109, 707-713 (1972)

Received July 12, 1976 